\title{
KEPEMIMPINAN \\ KRISTEN YANG EFEKTIF
}

Oleh:

Pdt.Jermia Djadi, M. Th.

\section{PENDAHULUAN}

Dalam sepanjang sejarah, kualitas kepemimpinan merupakan faktor penentu dalam keberhasilan suatu organisasi, baik dalam dunia usaha maupun dalam dunia pendidikan, pemerintahan, politik, kesehatan, dan agama, khsusnya agama Kristen. Organisasi apa pun di dunia ini pasti pernah mengalami kegagalan. Salah satu penyebabnya adalah faktor kepemimpinan yang kurang memadai. Menurut pengamatan penulis, masalah kepemimpinan masih merupakan kendala dalam pengembangan organisasi dan misi Kristen di Indonesia. Masalah kepemimpinan dan pemimpin merupakan kebutuhan yang urgen dalam suatu organisasi pada masa kini. "Kepemimpinan menjadi kunci pembuka bagi suksesnya organisasi" (Kartin Kartono 1991:v).

Makalah ini diberi judul "Kepemimpinan Kristen yang Efektif" tentang membahas hakikat kepemimpinan, karakter pemimpin Kristen, dan langkahlangkah praktis kepemimpinan Kristen.

\section{HAKIKAT KEPEMIMPINAN}

Arti Pemimpin dan Kepemimpinan

Arti Pemimpin

Beberapa perumusan tentang pemipin adalah sebagai berikut: (1) Pemimpin adalah orang yang membimbing dan mengarahkan orang-orang lain. (2) Pemimpin adalah orang yang dapat menggerakkan orang-orang lain untuk mengikuti jejaknya. (3) Pemimpin adalah orang yang berhasil menimbulkan perasaan ikut serta, perasaan ikut bertanggung jawab, kepada orang-orang bawahannya terhadap pekerjaan yang sedang dilakukan di bawah pimpinannya (Moekijat 1990:274). Jadi, yang dimaksud dengan pemimpin adalah orang yang melakukan kegiatan atau aktivitas, mempengaruhi orang lain dalam suatu situasi tertentu, melalui proses komunikasi, yang diarahkan guna mencapai tujuan tertentu (Pariata Westra, cs. 1989: 246).

\section{Arti Kepemimpinan}

Kepemimpinan (leadership) adalah proses pengaruh-mempengaruhi antarprinadi atau antarorang dalam suatu situasi tertentu, melalui aktivitas komunikasi yang terarah untuk mencapai suatu tujuan atau tujuan-tujuan terntentu. Dalam kepemimpinan selalu terdapat unsur pemimpin (influencer), yakni yang mempengaruhi tingkah laku pengikutnya (influencee) atau para pengikutnya dalam 
suatu situasi (Ibid. 1989: 246-247). Kepemimpinan rohani atau kepemimpinan Kristen memiliki otoritas ilahi yang lebih tinggi daripada kepemimpinan alamiah.

Bertolak dari pengertian pemimpin dan kepemimpinan di atas, maka dapat diidentifikasi unsur-unsur dalam kepemimpinan. Unsur-unsur yang dimaksud adalah: (1) Adanya seseorang yang berfungsi memimpin, yang disebut pemimpin (leader). (2) Adanya orang lain yang dipimpin. (3) Adanya kegiatan menggerakkan orang lain yang dilakukan dengan mempengaruhi dan mengarahkan perasaan, pikiran, dan tingkah lakunya. (4) Adanya tujuan yang hendak dicapai, baik yang dirumuskan secara sistematis maupun bersifat seketika. (5) Berlangsung berupa proses di dalam kelompok/organisasi, baik besar dengan banyak orang maupun kecil dengan sedikit orang yang dipimpin.

\section{Dinamika Kepemimpinan}

Pada masa lalu dan bahkan sekarang ini, banyak yang berpendapat bahwa kepemimpinan merupakan seni. Kepemimpina sebagai seni menempatkan bakat sebagai faktor yang penting dan berpengaruh besar terhadap kemampuan mewujudkannya. Bakat kepemimpinan sebagaimana bakat yang lain dimiliki oleh setiap orang, namun berbeda kualitas dan kuantitasnya antara yang satu dengan yang lainnya. Itu berarti kepemimpinan akan berlangsung efektif dan efisien di tangan orang yang kualitas bakatnya besar dan kualitasnya tinggi.

Di samping itu, ada pula yang berpendapat bahwa kepemimpinan merupakan ilmu. Oleh sebabitu, dapat diungkapkan, dianalisis, diuraikan, dan dilaksanakan secara ilmiah. Itu berarti kepemimpinan dapat dipelajari oleh semua aorang yang memerlukannya, sebagaimana mempelajari disiplin ilmu yang lainnya. Jadi, kepemimpinan sebagai ilmu menitikberatkan pada proses belajar dan latihan. Kepemimpinan akan berlangsung efektif dan efisien menurut pendapat ini bilamana berada di tangan orang yang terampil atau terlatih dan ahli dalam memimpin. Kepemimpinan itu dapat diperoleh melalui proses belajar dan melatih diri secara intensif. Untuk itu, seseorang harus menguasai teori-teori kepemimpinan yang bersifat ilmiah dan berusaha menerapkannya dalam praktik memimpin.

Kedua pendapat di atas dapat diterima kebenarannya dalam batas-batas tertentu. Pendapat bahwa kepemimpinan sebagai seni, tidak boleh menjadi ekstrim dengan menyatakan bahwa faktor bakat merupakan satu-satunya untuk mewujudkan kepemiminan yang sukses. Dengan kata lain, kepemimpinan tidak sepenuhnya bergantung pada bakat. Demikian pula pendapat bahwa kepemimpinan merupakan ilmu, tidak boleh menjadi ekstrim dengan menyatakan bahwa faktor bakat sama sekali tidak berperan dalam kepemimpinan.

Seseorang melalui proses belajar dapat memiliki pengetahuan yang banyak dan mendalam tentang kepemimpinan yang efektif dan efisien. Kemudian mungkin pula telah berusaha melatih diri untuk menjadi pemimpin yang sukses. Dalam kenyataannya tanpa memiliki atau hanya sedikit memiliki bakat memimpin, maka kepemimpinannya akan sulit berkembang dan dikembangkan. Kenyataan ini 
menunjukkan bahwa kepemimpinan sebagai masalah manusia sifatnya unik dan bervariasi, yang tidak mudah dijalankan jika hanya mengandalkan teori-teori dan manifestasinya dalam kegiatan yang dilakukan secarra rutin. Kepemimpinan yang bersifat situasional sangat memerlukan ketajaman penalaran yang harus didasari oleh intelegensi (faktor keturunan) yang memadai dan bakat-bakat penunjang lainnya di bidang kepemimpinan.

Pemimpin harus mampu menghargai kelebihan setiap orang dan dapat memanfaatkannya secara maksimal. Sebaliknya juga harus memahami kekurangan, kelemahan, dan keterbatasannya. Dengan kata lain, setiap orang harus diperlakukan sebagai subjek dengan selalu berusaha menghargai dan menyalurkan pikiran, pendapat, saran, inisiatif, kreativitas, dan bahkan keinginan dan tujuan kelompok. Sebaliknya, pemimpin juga tidak memaksakan kehendaknya, apabila tidak diterima oleh anggota kelompok pada umumnya (Hadari Nawawi dan M. Martini Hadari 2006:21-27).

\section{Fungsi Kepemimpinan}

Kepemimpinan yang efektif hanya akan terwujud apabila dijalankan sesuai dengan fungsinya. Fungsi kepemimpinan itu berhubungan langsung dengan situasi sosial dalam kehidupan kelompok masing-masing, yang mengisyaratkan bahwa setiap pemimpin berada di dalam dan bukan di luar situasi itu. Pemimpin harus berusaha menjadi bagian di dalam situasi sosial kelompoknya. Itu berarti, fungsi kepemimpin merupakan gejala sosial karena harus diwujudkan dalam interaksi antarindividu di dalam situasi sosial suatu kelompok.

Yokob Tomatala menjelaskan bahwa kepemimpinan melibatkan pemimpin dalam fungsi manajemen yang berikut.

Pertama, Fungsi kegiatan perencanaan, meliputi: (1) penaksiran hari esok; (2) menetapkan tujuan-target yang akan dicapai; (3) membangun policy kerja yang relevan; (4) membuat program pencapaian target; (5) menetapkan prosedur atau tahapan yang akan dilalui kepada target; (6) menetapkan jadwal kerja kepada target; (7) menetapkan dan mengadakan anggaran yang dibutuhkan untuk mencapai target.

Kedua, Fungsi kegiatan organisasi, meliputi: (1) membuat struktur organisasi; (2) melaksanakan delegasi; (3) menetapkan dan membina hubungan timbal balik antara pemimpin dan pekerja.

Ketiga, Fungsi kegiatan memimpin, meliputi: (1) membuat keputusan; (3) membina komunikasi terpadu-harmonis; (4) memberi motivasi bagi dan dalam tugas; (5) memilih orang yang tepat untuk tugas yang tepat pula; (6) mengembangkan setiap orang dalam dan untuk tugas yang dilaksanakan.

Keempat, Fungsi kegiatan pengawasan, meliputi: (l) menetapkan standar bagi tugas dan petugas; (2) Mengukur pekerjaan yang sedang dan telah dilaksanakan; (3) Mengevaluasi pekerjaan yang sedang dan telah dilaksanakan (Yakob Tomatala 1987). 


\section{KARAKTER PEMIMPIN KRISTEN}

Seorang pemimpin Kristen harus memiliki karakter yang baik apabila ia ingin menjadi pemimpin yang efektif. Seorang pemimpin Kristen yang hanya memiliki ilmu pengetahuan, keahlian, keterampilan, dan gelar yang tinggi, tanpa karakter yang baik, akan mengalami kehancuran dalam kariernya.

\section{Pengertian Karakter}

Karakter adalah kepribadian dalam diri kita, hasrat, keinginan, kehendak dalam diri kita. Karakter adalah kecenderungan kita. Karakter adalah perangai, tabiat, dan watak kita. Karakter adalah sosok asli dalam diri kita, yang secara tetap mempengaruhi perbuatan, perasaan, dan pikiran kita.

\section{Proses Pembentukan Karakter}

Karakter merupakan gabungan dari pembawaan lahir dan kebiasaan yang kita dapatkan dari orang tua dan lingkungan kita yang secara tidak sadar mempengaruhi seluruh perbuatan, perasaan, dan pikiran kita.

Faktor-faktor yang mempengaruhi proses pembentukan karakter, antara lain: Pembawaan lahir, meliputi: (1) Karunia rohani khusus dari Sang Pencipta; (2) Gabungan gen (plasma pembawaan sifat) dan kromosom yang kita warisi dari orang tua serta nenek moyang kita. (3) Jenis kelamin, ras, golongan darah, dan faktor fisik lainnya. (4) Kebiasaan-kebiasaan yang terbentuk dari orang tua, lingkungan, budaya, kepercayaan, dan pendidikan. Kebiasaan-kebiasaan tersebut mencakup mulai dari kebiasaan tidur, kebiasaan belajar, cara makan, cara bekerja, hingga cara bergaul dengan orang lain.

Dengan menyadari hal ini, kita dapat mengerti bahwa tidak ada manusia yang memiliki karakter yang $100 \%$ sama. Sebab itu, jangan heran atau iri hati bila kita tidak memiliki kelebihan atau kelemahan seperti orang lain (Chandra Suwondo 2007:3-4)

\section{Enam Pilar Karakter}

Josephson Institute of Ethics mendefinisikan enam inti dasar etika yang berhubungan dengan kewajiban moral dan kebaikan. Hal tersebut lebih dikenal dengan nama "enam pilar karakter."

Pertama, Trustworthiness (dapat dipercaya): (1) jujur; (2) tulus; (3) memegang janji; (4) tidak curang, menipu, atau mencuri; (5) dapat dipercaya, apa yang Andi katakan adalah hal yang Anda kerjakan (integritas); (6) berani melakukan hal yang benar; (7) membangun reputasi yang baik; (8) setia kepada keluarga, kawan, dan negara.

Kedua, Respect (memiliki rasa hormat), meliputi: (1) hormati Tuhan Allah; (2) hormati diri sendiri; (3) toleransi terhadap perbedaan; (4) berbicara dengan 
kata-kata yang baik, bukan dengan kata-kata yang kasar; (5) tidak menekan, memukul, atau menyakiti orang lain.

Ketiga, Resposibility (bertanggung jawab): (1) kerjakanlah hal yang harus Anda kerjakan; (2) kerjakanlah hal yang dapat Anda kerjakan dengan sebaikbaiknya; (3) tekun: tetaplah mencoba sampai berhasil; (4) belajarlah menguasai diri, untuk mendisiplinkan dirimu sendiri; (5) berpikirlah sebelum Anda bertindakpikirkanlah akibatnya; (6) bertanggung jawablah atas pilihanmu.

Keempat, Fairness (adil): (l) bermainlah sesuai dengan hukum (peraturan) yang ada; (2) ambillah hak Anda, jangan mengambil hak orang lain; (3) bersikaplah terbuka; dengarkan juga pendapat orang lain; (4) Jangan mengambil keuntungan dari kelemahan orang lain; (5) Jangan menyalahkan orang lain karena kesalahan Anda.

Kelima, Caring (peduli): (1) ramah dan baik hati; (2) Milikilah belas kasihan dan tunjukkan kepedulian Anda; (3) nyatakan rasa syukur Anda; (4) ampunilah orang lain; (5) bantulah saat seseorang membutuhkan bantuan tersebut.

Keenam, Citizenship (memiliki tanggung jawab sosial): (1) ikut serta dalam layanan masyarakat; gunakan hak suara Anda; (2) jadikanlah tetangga yang baik; (3) taat pada hukum dan peratuan; (4) Hormatilah penguasa Anda; (5) jagalah lingkungan Anda (Ibid.: 5-7)

\section{Nilai Suatu Karakter}

Pertama, Karakter tulus. Karekter tulus menempati peringkat pertama sebagai karakter yang paling disukai oleh semua orang. Ketulusan membuat orang lain merasa aman, tidak khawatir dicurigai atau dibohongi. Orang yang mempunyai karakter tulus selalu mengatakan hal yang sebenarnya. Ia tidak pernah mengada-ada, berpura-pura, mencari-cari alasan, atau memutarbalikkan fakta. Ia mempunyai prinsip untuk mengatakan bahwa "ya adalah ya" dan "tidak adalah tidak" (Yakobus 5:12b). Hal yang ideal ialah "tulus seperti merpati, tetapi cerdik seperti ular."

Kedua, Karakter setia. Karakter setia merupakan karakter yang sudah menjadi barang langka dan sangat mahal harganya. Orang yang berkarakter setia, selalu dapat dipercaya dan diandalkan (l Timotius 1:12). Ia selalu menepati janjinya, mempunyai komitmen yang kuat, rela berkorban, dan tidak mempunyau karakter berkhianat.

Ketiga, Karakter rendah hati. Rendah hati berbeda dengan rendah diri yang merupakan kelemahan. Karakter rendah hati justru mengungkapkan kekuatan diri. Hanya orang yang kuat jiwanya yang dapat berlaku rendah hati. Ia seperti padi yang semakin berisi semakin menunduk. Orang yang rendah hati bisa mengakui dan menghargai keunggulan orang lain; ia dapat membuat orang yang berada di atasnya merasa dihargai dan membuat orang yang berada di bawahnya tidak merasa minder (Filipi 2:3-4).

Keempat, Karakter easy going atau ceria. Karakter easy going atau ceria merupakan karakter yang mempermudah seseorang untuk dapat merasakan 
kebahagiaan hidup. Tidak semua orang mempunyai karakterini, keceriaan tidaklah diartikan dari ekspresi wajah atau tubuh seseorang, tetapi dari kecenderungan sikap hati. Orang ceria merupakan orang yang dapat menikmati hidup, tidak suka mengeluh, dan selalu berusaha meraih kebahagiaan. Ia cenderung untuk menghibur dan memberikan semangat kepada orang lain. Orang ceria menganggap hidup ini ringan. Ia tidak suka memperbesar masalah kecil, bahkan ia membuat masalah besar menjadi kecil. Ia tidak suka mengungkit masa lalu dan tidak khawatir tentang masa depan. Ia tidak mau pusing dan stress tentang masalah-masalah yang berada di luar kontrolnya (Filipi 3:13-14).

Kelima, Karakter empati. Karakter empati merupakan karakter yang sangat mengagumkan. Orang yang berempati bukan saja seorang pendengar yang baik, namun ia juga bisa menempatkan diri pada posisi orang lain. Saat terjadi konflik ia selalu berusaha mencari jalan keluar terbaik bagi kedua belah pihak. Ia tidak memaksanakan pendapat dan kehendaknya sendiri. Ia selalu berusaha memahami dan mengerti orang lain.

Keenam, Karakter percaya diri. Karakter percaya diri hanya dimiliki oleh orang yang dapat menerima dirinya, sebagaimana adanya, dapat menghargai dirinya dan orang lain. Orang yang percaya diri mudah menyesuaikan diri dengan lingkungan dan situasi yang baru. Ia mengetahui apa yang harus dilakukannya dan dapat melakukannya dengan baik. Saat menghadapi kesulitan, ia tetap tegar serta tidak membiarkan dirinya terhanyut dalam kesedihan dan keputusasaan.

Ketujuh, Karakter bertanggung jawab. Karakter bertanggung jawab merupakan karakter untuk melaksanakan kewajiban dengan sungguh-sungguh. Apabila melakukan kesalahan, ia berani mengakuinya. Saat mengalami kegagalan, ia tidak akan mencari kambing hitam untuk disalahkan. Bahkan saat ia merasa kecewa dan sakit hati, ia tidak akan menyalahkan siapa pun, Ia menyadari bahwa dirinya sendirilah yang bertanggung jawab atas hal apa pun yang dialami dan dirasakannya.

Kedelapan, Karakter optimis. Orang yang memiliki karakter optimis selalu berusaha melihat segala sesuatu dari kacamata positif, bahkan dalam situasi yang buruk sekalipun. Ia lebih suka membicarakan "kebaikan" daripada "keburukan" orang lain. Ia lebih suka mencari "solusi" daripada "frustrasi", lebih suka "memuji" daripada "mengecam." (Ibid.: 8-lI). "Jadi, akhirnya saudara-saudara, semua yang benar, semua yang mulia, semua yang adil, semua yang suci, semua yang mulia, semua yang sedap didengar, semua yang disebut kebajikan dan patut dipuji, pikirkanlah semua itu" (Filipi 4:8).

\section{Karakter Menurut Golongan Darah}

Berikut ini secara khusus kita akan mempelajari karakter menurut golongan darah, yaitu golongan darah $\mathrm{A}$, golongan darah $\mathrm{B}$, golongan darah $\mathrm{O}$, dan golongan darah $\mathrm{AB}$. 
Pertama, Golongan darah A. Biasanya orang-orang yang bergolongan darah A mempunyai kecenderungan: (1) Berkepala dingin, serius, sabar, dan tenang. (2) Tegas, dapat diandalkan, dan dipercaya, tetapi keras kepala. (3) Sebelum melakukan sesuatu mereka memikirkannya terlebih dahulu, merencanakan segala sesuatu secara matang. (4) Mereka mengerjakan segalanya dengan sungguh-sungguh dan secara konsisten. (5) Mereka berusaha membuat diri mereka sewajar dan seideal mungkin. (6) Mereka bisa menyendiri dan menjauhi orang lain. (7) Mercka mencoba menekan perasaan mereka dan tegar, tetapi sebenarnya mereka mudah stres dan tertekan. (8) Mereka cenderung keras terhadap orang-orang yang tidak sependapat, karena itu, mereka cenderung berada di sekitar orang-orang yang berkarakter sama.

Kedua, Golongan darah B. Biasanya orang-orang yang bergolongan darah B mempunyai kecenderungan: (1) Penasaran dan tertarik terhadap segala hal. (2) Mereka cenderung mempunyai banyak hobi dan kegemaran. Bila menyukai sesuatu, mereka menggebu-gebu, tetapi cepat bosan. (3) Biasanya mereka dapat menentukan hal terpenting untuk dikerjakan. (4) Mereka cenderung ingin menjadi nomor satu dalam berbagai hal ketimbang hanya dianggap rata-rata. (5) Mereka cenderung mengabaikan sesuatu, jika terfokus pada kesibukan lain. Dengan kata lain, mereka tidak dapat mengerjakan sesuatu sccara bersamaan. (6) Mereka terlihat cemerlang, riang, bersemangat, dan antusias, namun sebenarnya berbeda dengan hal yang ada dalam diri mereka. (7) Mereka biasanya tidak ingin bergaul dengan banyak orang. (8) Mereka tidak suka ada sesuatu yang statis dan mudah tertidur di mana saja, tetapi mereka juga rentan terhadap bunuh diri.

Ketiga, Golongan darah O. Biasanya orang-orang yang bergolongan darah $\mathrm{O}$ mempunyai kecenderungan: (l) Berperan dalam menciptakan gairah dan keharmonisan dalam suatu kelompok. (2) Figur mereka terlihat sebagai orang yang menerima dan melakukan sesuatu dengan tenang. Mereka pandai menutupi sesuatu, hingga mereka terlihat selalu riang, damai, dan tidak punya masalah. Bila tidak tahan, mereka akan mencari orang terdekatnya untuk berkeluh kesah. (3) Mereka biasanya pemurah, senang berbuat baik. Mereka dermawan dan tidak segan-segan mengeluarkan uang untuk orang lain. (4) Mereka biasanya dapat diterima semua kelompok orang. (5) Mereka sebenarnya keras kepala dan secara tersembunyi mempunyai pendapat tersendiri tentang berbagai hal. (6) Mereka fleksibel dan sangat mudah menerima hal-hal baru. (7) Mereka cenderung mudah dipengaruhi orang lain dan dengan apa yang mereka lihat. (9) Mereka terlihat berkepala dingin dan terpercara, tetapi mereka sering tergelincir dan membuat kesalahan besar karena kurang berhati-hati. (10) Bila berpacaran kadang mudah lepas kendali.

Keempat, Golongan darah AB. Biasanya orang-orang yang bergolongan darah AB mempunyai kecenderungan: (1) Mempunyai perasaan sensitif dan lembut. (2) Mereka penuh perhatian terhadap perasaan orang lain dan selalu menghadapi orang lain dengan kepedulian serta kehati-hatian. (3) Mereka keras terhadap diri sendiri serta orang yang dekat dengan mereka. (4) Mereka cenderung kelihatan mempunyai dua kepribadian atau kepribadian ganda dan susah ditebak apa maunya. (5) Mereka 
sering menjadi orang yang sentimen dan memikirkan sesuatu terlalu dalam. (6) Mereka mempunyai banyak teman, tetapi mereka membutuhkan waktu menyendiri untuk memikirkan persoalan mereka sendiri (Ibid.: 19-22).

Hal-hal yang baik dan positif dari karakter menurut golongan darah $\mathrm{A}, \mathrm{B}, \mathrm{O}$, dan $A B$ hendaknya dipertahankan dan ditingkatkan, sedangkan hal-hal yang kurang baik dan negatif hendaknya dijadikan sebagai warning dan awasan bagi kita.

\section{Cara Tuhan Membentuk Karakter Kita}

Tuhan membentuk karakter kita melalui segala kesulitan dan kesedihan. Tuhan memperbaiki karakter kita melalui semua kegagalan dan air mata. Tuhan memperindah karakter kita melalui sayatan tajam yang menyakitkan. Tuhan menyempurnakan karakter kita, membuat kita menjadi indah dan berkenan di hadapan Tuhan.

\section{LANGKAH-LANGKAH PRAKTIS KEPEMIMPIN}

Dalam bab ini akan dibahas lima langkah praktis kepemimpinan sebagai strategi kepemimpinan Kristen yang efektif. Lima langkah tersebut meliputi berdoa, bekerja keras, memotivasi, mendelegasikan tugas, dan menggunakan tipa kepemimpinan demokratis.

\section{Langkah Pertama: Berdoa}

Hal berdoa penulis tempatkan pada urutan pertama dalam langkah-langkah praktis kepemimpinan Kristen yang efektif. Itu berarti hal berdoa merupakan prioritas utama dalam kepemimpinan Kristen yang ingin berhasil dalam pelayanannya. Walaupun kita mampu dalam banyak hal, tetapi jangan lupa berdoa. Jangan menggantikan hikmat Allah dengan hikmat manusia. Oleh sebab itu, sebagai pemimpin Kristen, doa merupakan hal penting dan harus diutamakan dari semua kegiatan lainnya. Berilah waktu yang cukup untuk berdoa. Mengutakan doa adalah syarat mutlak bagi pemimpin Kristen yang berhasil.

J. Oswald Sanders berkata, Para pemimpin yang benar dalam Alkitab dikenal karena mereka adalah pahlawan-pahlawan doa yang benar. Mereka menjadi pemimpin bukan karena kehebatan pikiran mereka, bukan karena mereka mempunyai sumber yang tidak ada habis-habisnya, bukan karena kebudayaan atau bakat-bakat pembawaan mereka sejak lahir yang hebat, melainkan karena kuasa doa, maka mereka dapat memiliki kuasa Allah (J. Oswald Sander 1974:93).

Nehemia, Daniel, Daud, Yosua, Yakobus, Paulus dan lain-lain telah menjadi pemimpin besar yang sungguh-sungguh berhasil dalam pelayanannya karena mengutamakan doa dan hidup di dalam doa. Doa adalah prioritas utama dalam kepemimpinan rohani yang kuat. Doa membuat pelayanan penuh kuasa. Berdoa bukan berarti merampas waktu belajar, bekerja atau kegiatan-kegiatan pelayanan lain, tetapi berdoa harus didahulukan sebelum melakukan kegiatan-kegiatan lain. 
Karena, baik belajar maupun melakukan kegiatan-kegiatan pelayanan dapat disegarkan dan dijadikan berhasilguna oleh doa. Doa yang mempengaruhi pelayanan seseorang haruslah mempengaruhi hidupnya sendiri.

Pada masa kini, dalam dunia yang semakin maju, gereja dan pemimpin Kristen pun telah dilengkapi dengan pengetahuan yang luas, sarana, dan prasarana yang memadai. Walaupun hal iru diperlukan, semuanya itu tidaklah membuat seorang pemimpin berhasil dalam melaksanakan tugas pelayanannya. Yang aling utama yang diperlukan gereja pada masa kini adalah pemimpin-pemimpin yang suka berdoa dan mengutamakan doa. Karena, setiap pelayanan yang benar-benar berhasil secara rohani, doa adalah suatu kekuatan nyata yang mengontrol kehidupan pemimpin Kristen dan yang megontrol pekerjaannya.

\section{Langkah Kedua: Beberja Keras}

Sesuai dengan pepatah Latin yang berbunyi, "Ora et Labora," yang artinya berdoa dan bekerja, maka bekerja keras merupakan langkah praktis yang kedua dari kepemimpinan rohani yang efektif. John White dalam bukunya yang berjudul Pemimpin yang Handal berkata, "Doa mungkin memindahkan gunung. Tetapi doa dan kerja keras merupakan perpaduan yang sungguh menakjubkan. Keduanya bergandengan membuat proyek-proyek besar berjalan lancar ... tidak ada sesuatu pun yang terlaksana bagi Allah tanpa bekerja. Juga tidak ada seorang pun yang telah dipakai secara luar biasa, kecuali ia-pria maupun wanita telah bekerja keras seolaholah mengerjakan pekerjaan dua orang" (John White 1994:70,74).

Maksud pernyataan di atas ialah bahwa seorang pemimpin yang berhasil tidak cukup hanya berdoa tanpa bekerja keras. Doa merupakan prioritas utama dalam kepemimpinan Kristen, tetapi doa harus disertai dengan bekerja keras. Pemimpinpemimpin rohani harus bekerja keras bahkan justru bekerja paling keras. Mereka sering masih bekerja sementara yang lain tertidur, berekreasi, dan sebagainya. Kerja keras inilah yang menyebabkan mereka berhak disebut pemimpin. Tetapi, yang dimaksud bekerja keras ialah sungguh-sungguh bekerja, yaitu berusaha menyelesaikan tugas dengan penuh tanggung jawab.

Di dalam Alkitab, semua pemimpin yang berhasil karena bekerja keras di samping berdoa sebagai prioritas utama dalam kepemimpinannya. Nehemia telah bekerja keras dengan tidak menyayangkan apa pun juga. Bagi dia kepemimpinan itu bukan sebuah jabatan yang membebaskan dia dari tugas dan kewajiban demi memusatkan perhatiannya pada pekerjaan yang lebih penting. Ketika ia pertama kali berbicara kepada orang-orang Yahudi di Yerusalem, ia berkata dengan suara yang nyaring, "Mari kita bangun kembali tembok Yerusalem"(Nehemia 2:17). Dalam kitab Nehemia pasal 4, Nehemia ikut terjun dalam pekerjaan pisik dan ikut menanggulangi kesulitan-kesulitan yang ada (Nehemia 4:21-23). Tuhan Yesus sendiri adalah seorang pekerja. Dalam Injil Yohanes 9:4 la berkata, "Kita harus mengerjakan pekerjaan-pekerjaan Dia yang mengutus Aku, selama masih siang, akan datang malam, di mana tidak ada seorang pun yang dapat bekerja." Ketika 
orang-orang Yahudi berusaha menganiaya Yesus karena melakukan penyembuhan pada hari Sabat, maka la berkata kepada mereka, "Bapa-Ku bekerja sampai sekarang, maka Aku pun bekerja juga" (Yohanes 4:17). Kedua belas murid Tuhan Yesus adalah pekerja. Ketujuh puluh murid Yesus yang diutus adalah pekerja. Rasul Paulus adalah pekerja. Ia telah bekerja keras lebih dari mereka yang lain (1 Korintus 3:9). Ia memperingatkan jemaat untuk "menghormati mereka yang bekerja di antara kamu yang memimpin kamu dalam Tuhan" (1 Tes. 5:12).

Seorang pemimpin yang ingin mengikuti teladan Kristus dan teladan para murid yang telah dipilih dan dilatih-Nya harus bekerja keras. Kalau orang dalam dunia bisnis bekerja keras untuk memperoleh laba yang sifatnya sementara, apalagi kita yang bekerja dalam ladang Tuhan. Kita sebagai pemimpin Kristen sudah seharusnya memberikan contoh dengan bekerja keras, sehingga orang-orang yang dipimpin juga meneladani untuk bekerja keras. Kita harus bekerja keras untuk membangun kerajaan Allah sampai Tuhan datang kembali.

\section{Langkah Ketiga: Memotivasi}

Arti Memotivasi.

Memotivasi (motivating) dapat didefinisikan, "Keseluruhan proses pemberian motif bekerja kepada para bawahan sedemikian rupa sehingga mereka mau bekerja dengan ikhlas demi tercapainya tujuan organisasi dengan efisien dan ekonomis" (Sondang P. Siagian 1988:128).

Memperhatikan arti dari memotivasi di atas, itu berarti bukan hanya pemimpin yang bekerja keras, tetapi bersama-sama dengan para bawahannya. Dengan memotivasi atau menggerakkan para bawahan untuk bekerja, pemimpin dapat mengerjakan hal-hal khusus yang tidak dapat dikerjakan oleh orang lain sehingga lebih banyak pekerjaan dapat dikerjakan secara efisien dan ekonomis, tetapi dengan hasil yang maksimal demi tercapainya tujuan organisasi.

\section{Tujuan Memotivasi.}

Adapun tujuan memotivasi yang diberikan oleh pemimpin pada umumnya adalah untuk: Pertama, Meningkatkan asosiasi dan integrasi kelompok dan menjamin keterpaduan. Kedua, Menjamin efektivitas dan efisiensi kerja semua anggota kelompok. Ketiga, Meningkakan partisipasi aktif dan tanggung jawabsosial semua anggota. Keempat, Meningkatkan produktivitas semua sektor dan anggota kelompok. Kelima, Menjamin terlaksananya realisasi diri dan pengembangan diri pada setiap anggota kelompok dan memberi kesempatan untuk melakukan ekspresi bebas (Kartini Kartono 1991: 94).

\section{Cara Memotivasi.}

Memotivasi dapat dilakukan dengan lima cara sebagai berikut:

Pertama, Melalui sentuhan tubuh. Roh atau jiwa manusia dapat dipuaskan dengan jalan sentuhan tubuh. Sentuhan tubuh dapat dilakukan dengan tersenyum, 
berjabat tangan, menepuk bahu, dsb., yang dilakukan dengan penuh kesopanan serta pengharapan kepada bawahan sebagai subjek.

Kedua, Melalui sentuhan rohani. Sentuhan rohani dapat dilakukan dengan memberikan nasihat, ajaran, hikmat, dsb.

Ketiga, Melalui proses individu-psikologis. Sentuhan psikologis dapat berupa pujian (praising) atau teguran (reprimed) sesuai dengan kondisi langsung dari setiap bawahan.

Keempat, Motivasi sukses. Motivasi sukses disimbolkan dengan memberi penghargaan sebagai tanda prestasi. Motivasi sukses apabila dilakukan dengan bijaksana akan memberi dorongan yang kuat untuk bekerja dengan lebih giat atau bersemangat.

Kelima, Motivasi diri. Motivasi diri adalah upaya membangun semangat diri dengan sugesti diri secara positif. Motivasi diri bertujuan menjaga kestabilan sikap serta tekad untuk terus maju dan berprestasi (Yakob Tomatala (1996: 205-207).

\section{Langkah Keempat: Mendeligasikan Tugas}

Mendelegasikan tugas merupakan langkah praktis yang keempat dalam kepemimpinan Kristen sebagai strategi kepemimpinan yang efektif. Hal mendelegasikan tugas ini akan dibahas dalam beberapa segi, yaitu pengertian, tujuan, manfaat, dan hal-hal yang perlu diperhatikan dalam pendelegasian tugas.

\section{Pengertian Pendelegasian.}

Yakob Tomatala dalam bukunya yang berjudul Kepemimpinan yang Dinamis memberikan pengertian pendelegasian tugas sebagai berikut. Pertama, Pendelegasian ialah proses terorganisasi dalam kerangka hidup organisasi untuk melibatkan sebanyak mungkin orang secara langsung dan pribadi dalam pembuatan keputusan, pengarahan, dan pengerjaan kerja berkaitan dengan kapasitas tugas. Kedua, Pendelegasian ialah tindakan kepercayaan tugas yang pasti dan jelas, kewenangan, hak, tanggung jawab, kewajiban, dan pertanggungjawaban kepada bawahan secara individu dalam setiap posisi tugas. Pendelegasian dilakukan dengan cara membagi tugas, kewenangan, hak, tanggung jawab, kewajiban, serta pertanggungjawaban yang diterapkan dalam suatu penjabaran tugas formal dalam organisasi (Yakob Tomatala 1996:186).

Berdasarkan kedua pengertian di atas dapat disimpulkan bahwa pendelegasian dari pimpinan kepada orang yang diberikan tugas adalah bersifat formal, pasti, dan jelas mekanismenya.

\section{Tujuan Pendelegasian.}

Seorang pemimpin dalam mendelegasikan tugas kepada orang lain mempunyai tujuan sebagai berikut. Pertama, Untuk mendapatkan orang-orang lain yang cakap untuk melakukan tugas-tugas, baik waktu darurat maupun waktuwaktu yang akan datang. Kedua, Dengan pendelegasian, banyak orang dilibatkan 
dalam tugas kepemimpinan sehingga mencegah kegagalan yang mungkin timbul. Ketiga, Dengan pendelegasian yang tepat, maka pekerjaan dapat dilaksanakan lebih banyak dan lebih baik. Dalam pendelegasian tersebut, pemimpin harus membuat perhitungan yang tepat tentang orang yang mendapat tugas pendelegasian itu. Yang harus diperhitungkan adalah kepribadian orang tersebut, kualitas, dan karunia rohani, bakat, dan kesanggupannya. Pendelegasian itu harus dilakukan secara tahap demi tahap dan harus pula disertai dengan pengawasan serta laporan kembali ( $\mathrm{P}$. Oktavianus 1986:21,23).

\section{Manfaat Pendelegasian.}

Dengan mendelegasikan tugas kepada orang lain akan diperoleh manfaat sebagai berikut. Pertama, Pemimpin dapat melakukan tugas yang pokok-pokok saja. Kedua, Tiap-tiap tugas dapat diselesaikan pada jenjang yang tepat. Ketiga, Putusan dapat dibuat dengan lebih tepat. Keempat, Dapat dihilangkan sikap selalu menunggu perintah sehingga pekerjaan dapat berjalan lebih lancar. Kelima, Inisiatif dapat ditingkatkan. Keenam, Rasa tanggung jawab dapat diperbesar. Ketujuh, Tugas-tugas melayani masyarakat akan tetap berjalan walaupun pejabat yang bersangkutan sedang berhalangan. Kedelapan, Sebagai latihan bagi para pejabat apabila kelak menduduki jabatan yang lebih tinggi (Pariata Wesra, dkk. 1969:114).

\section{Hal-Hal yang Perlu Diperhatikan Dalam Pendelegasian.}

Ada beberapa hal yang perlu diperhatiakn oleh seorang pemimpin dalam pendelegasian tugas, antara lain: Pertama, Definisikan tugas-tugas yang harus didelegasikan. Kedua, Definisikan dengan jelas batas-batas wewenang yang dilimpahkan kepada seseorang. Ketiga, Tentukan dengan jelas batas-batas wewenang yang dilimpahkan kepada seseorang. Keempat, Jelaskan bagaimana, kapan, dan kepada siapa diserahi suatu tugas dan harus melapor kembali. Keenam, Tentukanlah cara pengawasan. Kedelapan, Pikirkanlah bagaimana orang itu harus disiapkan untuk tugas yang didelegasikan. Kesembilan, Pendelegasian harus diikuti dengan kepercayaan bahwa orang yang mendapat tugas itu dapat menyelesaikan tugasnya. Kesepuluh, Berikan penghargaan kepada mereka yang menyelesaikan tugas dengan baik, karena penghargaan juga memberikan kesukaan dan sekaligus kunci keberhasilan dalam pendelegasian (P.Octavianus 1986:23).

\section{Langkah Kelima: Menggunakan Tipe Kepemimpinan Demokratis}

Dari semua tipe kepemimpinan yang ada, penulis memilih tipe kemimpinan demokratis sebagai langkah praktis yang kelima dalam kepemimpinan Kristen yang efektif. Hal ini cukup beralasan, sebab "pengetahuan tentang kepemimpinan telah membuktikan bahwa tipe kepemimpinan yang demokratislah yang paling tepat untuk organisasi modern" (Sondang P. Siagian 1988:48). Baik di kalangan ilmuwan maupun dikalangan praktisi terdapat kesepakatan bahwa tipe pemimpin yang paling ideal dan paling didambakan adalah pemimpin yang demokratis. Memang umum 
mengakui bahwa pemimpin yang demokratis tidak selalu merupakan pemimpin ang paling efektif dalam kehidupan organisasi karena ada kalanya dalam hal mengambil keputusan bisa terjadi keterlambatan sebagai konsekuensi keterlambatan para bawahan dalam proses pengambilan keputusan tersebut. Tetapi, dengan berbagai kelemahannya, pemimpin yang demokratis tetap dipandang sebagai pemimpin terbaik karena kelebihan-kelebihannya.

Berikut ini akan dikemukakan kelebihan atau keunggulan tipe kepemimpinan demokratis.

Pertama, Pemimpin demokratis merupakan pembimbing yang baik bagi kelompoknya. Dia menyadari bahwa tugasnya ialah mengkoordinasikan pekerjaan dan tugas dari semua anggotanya, dengan menekankan rasa tanggung jawab dan kerja sama yang baik kepada setiap anggota. Dia tahu bahwa organisasi atau lembaga bukanlah masalah pribadi atau individual, akan tetapi kekuatan organisasi terletak pada partisipasi aktif setiap anggota. Dia mau mendengarkan nasihat dan sugesti semua pihak dan mampu memanfaatkan keunggulan setiap orang seefektif mungkin pada saat-saat yang tepat. Dia sadar bahwa dia tidak mampu bekerja seorang diri. Karena itu, dia perlu mendapat bantuan dari semua pihak. Dia memerlukan dukungan dan partisipasi dari bawahannya, perlu mendapat penghargaan dan dorongan dari atasan dan perlu mendapatkan dukungan moril dari teman sejawat yang sederajat kedudukannya dengan dirinya. Dengan demikian, orgnisasi yang dipimpinnya akan terus berjalan lancar sekalipun dia tidak ada di tempat. Sebab otoritas sepenuhnya didelegasikan kepada bawahan sehingga semua orang merasa pasti dan aman, juga merasa senang menunaikan tugas-tugasnya.

Kedua, Pemimpin yang demokratis itu bisa berfungsi sebagai katalisator yang bisa mempercepat proses-proses secara wajar dan membantu pencapaian objek yang ingin dicapai dengan cara yang paling sesuai dengan kondisi kelompok tersebut.

Ketiga, Pemimpin demokratis biasanya dihormati dan dihargai (bukan ditakuti). Dia dianggap sebagai simbol kebaikan, karena ia bersedia bekerja sama dengan semua anggota kelomok. Pemimpin demokratis ini tidak berusaha menjadi "majikan." Semua anggota kelompok ingin bertemu muka dan bertukar pikiran dengan dirinya yang dianggap sangat simpatik. Semua prestasi kerjanya selalu dinilai dengan kriteria "hasil kami bersama", "modal kami", "hasil musyawarah bersama." Ringkasnya bentuk-bentuk kesuksesan selalu diungkapkan dalam bentuk kerja sama atau bentuk "kekamian."

Keempat, Pemimpin demokratis tidak menganggap diri sendiri sebagai superman dengan kemampuan-kemampuan superior, akan tetapi menganggap diri sendiri sebagai anggota biasa. Dia tidak pernah memberikan perintah tanpa menjelaskan pentingnya masilah dan selalu menerangkan secara terinci semua detail pelaksanaanya. Juga mendiskusikan semua masalah dengan kelompoknya. Ia memperlakukan orang-orang yang dibawahinya sebagai coworkers atau sesama kawan kerja dan tidak pernah menganggap mereka sebagai instrumen. Informasi 
mengeni kemajuan organisasi atau lembaga selalu diberikan; lalu dia menjelaskan rencana dan kemungkinan bagi perkembangan masa mendatang sehingga semua anggota mengetahui apa yang harus diperbuat setiap hari dan untuk apa mereka melakukan semuanya. Dia bisa menciptakan iklim psikis yang memberikan sekuritas emosional sehingga setiap orang dirangsang untuk bertingkah laku positif dan jujur.

Kelima, Dalam kepemimpinan demokratis ada penekanan pada disiplin diri, dari kelompok untuk kelompok dalam suasa demokratis. Maka delegasi otoritas dalam iklim demokratis itu bukan berarti hilangnya kekuasaan pemimpin, tetapi justru memperkuat posisi pemimpin yang didukung oleh semua anggota. Pemimpin bisa mengkristalisasikan pikiran serta aspirasi dari semua anggota kelompok dalam perbuatan yang nyata. Semua permasalahan dihadapi dan dipecahkan secara bersama-sama. Ia juga mengutamakan kerja kooperatif untuk tujuan pemupukan gairah kerja, peningkatan produktivitas, peningkatan moral, usaha perbaikan kondisi sosial pada umumnya. Dengan demikian, bisa dipahami bahwa kepemimpinan demokratis itu pada umumnya lebih superior daripada kepemimpinan lainnya (Kartini Kartono 1991:164-168).

Untuk menjadi pemimpin tipe demokratis bukanlah suatu hal yang mudah untuk dicapai. Akan tetapi karena ini merupakan tipe kemimpinan yang paling ideal, alangkah baiknya jika semua pemimpin berusaha menjadi pemimpin yang demokratis dan menerapkannya dalam melaksanakan tugas kepemimpinan Kristen yang efektif.

\section{KESIMPULAN}

Dari semua uraian di atas dapat disimpulkan sebagai berikut: Pertama, Dalam kepemimpinan terkandung beberapa unsur, yaitu adanya pemimpin, ada orang yang dipimpin, adanya kegiatan menggerakkan orang lain dengan mempengaruhi dan mengarahkan perasaan, pikiran, dan tingkah lakunya, dan adanya tujuan yang hendak dicapai. Kedua, Kepemimpinan merupakan seni dan ilmu. Kepemimpinan sebagai seni menempatkan faktor penting dalam kepemimpinan. Kepemimpinan sebagai ilmu berarti kepemimpinan dapat dipelajari. Kepemimpinan sebagai ilmu menitikberatkan pada proses belajar dan latihan. Apabila keduanya digabungkan, maka akan tercipta suatu kepemimpinan yang efektif. Ketiga, Kepemimpinan melibatkan pemimpin dalam fungsi manajenen yang meliputi fungsi kegiatan perencanaan, fungsi organisasi, fungsi kegiatan memimpin, dan fungsi kegiatan pengawasan. Keempat, Ada lima langkah praktis kepemimpinan sebagai strategi kepemimpinan Kristen yang efektif yang perlu diterapkan dalam memimpin organisasi, yaitu berdoa, bekerja keras, memotivasi, mendelegasikan tugas, dan menggunakan tipe kepemimpinan demokratis. Kelima langkah praktis kepemimpinan tersebut merupakan mata rantai yang berkaitan satu dengan yang lain, yang tidak dapat dipisahkan, sehingga membentuk kesatuan yang utuh sebagai kunci keberhasilan dalam kepemimpinan Kristen yang efektif. 
. Kepemimpinan yang Dinamis. Jakarta: YT Leadership Foundation, 1997.

Abdipatra, Budi. Leadership Plus. Yogyakarta: Andi Ofset, 2008.

Alkitab. Jakarta: Lembaga Alkitab Indonesia, 2000.

Engstrom, Ted W. \& Edward R. Dayton. Seni Manajemen Bagi Pemimpin Kristen.

Bandung: Yayasan Kalam Hidup, 1998.

Kartono, Kartini. Pemimpin dan Kepemimpinan. Jakarta: Rajawali Press, 1991.

Moekijat. Kamus Manajemen. Bandung: Penerbit Mandar Maju, 1990.

Nawawi, Hadari dan M. Martini Hadari. Kepemimpinan yang Efektif. Yogyakarta:

Gajah Mada University Press, 2006.

Octavianus, P. Manajemen dan Kepemimpinan Menurut Wahyu Allah. Malang: Penerbit Gandum Mas, 1986.

Sanders, J. Oswald. Kepemimpinan Rohani. Bandung: Yayasan Kalam Hidup, 1979.

Siagian, Sondang P. Teori dan Praktek Kepemimpinan. Jakarta: Rineka Cipta, 1991.

Suwondo, Chandra. Karakter Keindahan Sejati dari Manusia. Jakarta: Metanoia, 2007.

Tomatala, Yakob. Penatalayanan Gereja yang Efektif di Dunia Modern. Malang: Penerbit Gandum Mas, 1987.

Westra, Pariata. Ensiklopedi Administrasi. Jakarta: CV Haji Masagung, 1989.

White, John. Pemimpin yang Handal. Bandung: Yayasan Kalam Hidup, 2001. 